\title{
Efficacy of Flushing and Chlorination in Removing Microorganisms from a Pilot Drinking Water Distribution System
}

\author{
Nikki van Bel ${ }^{1, *}$, Luc M. Hornstra ${ }^{1}$, Anita van der Veen ${ }^{1}$ and Gertjan Medema ${ }^{1,2}$ \\ 1 KWR Watercycle Research Institute, P.O. Box 1072, 3430 BB Nieuwegein, The Netherlands; \\ Luc.Hornstra@kwrwater.nl (L.M.H.); Anita.van.der.Veen@kwrwater.nl (A.v.d.V.); \\ Gertjan.Medema@kwrwater.nl (G.M.) \\ 2 Sanitary Engineering, Department of Water Management, Faculty of Civil Engineering and Geosciences, \\ Delft University of Technology, P.O. Box 5048, 2600 GA Delft, The Netherlands \\ * Correspondence: Nikki.van.Bel@kwrwater.nl; Tel.: +31-30-606-9516
}

Received: 22 March 2019; Accepted: 24 April 2019; Published: 29 April 2019

\begin{abstract}
To ensure delivery of microbiologically safe drinking water, the physical integrity of the distribution system is an important control measure. During repair works or an incident the drinking water pipe is open and microbiologically contaminated water or soil may enter. Before taking the pipe back into service it must be cleaned. The efficacy of flushing and shock chlorination was tested using a model pipe-loop system with a natural or cultured biofilm to which a microbial contamination (Escherichia coli, Clostridium perfringens spores and phiX174) was added. On average, flushing removed 1.5-2.7 log microorganisms from the water, but not the biofilm. In addition, sand added to the system was not completely removed. Flushing velocity $(0.3$ or $1.5 \mathrm{~m} / \mathrm{s})$ did not affect the efficacy. Shock chlorination $(10 \mathrm{mg} / \mathrm{L}, 1-24 \mathrm{~h})$ was very effective against $E$. coli and phiX174, but C. perfringens spores were partly resistant. Chlorination was slightly more effective in pipes with a natural compared to a cultured biofilm. Flushing alone is thus not sufficient after high risk repair works or incidents, and shock chlorination should be considered to remove microorganisms to ensure microbiologically safe drinking water. Prevention via hygienic working procedures, localizing and isolating the contamination source and issuing boil water advisories remain important, especially during confirmed contamination events.
\end{abstract}

Keywords: chlorination; flushing; drinking water distribution system; water quality; contamination; cleaning

\section{Introduction}

Due to extensive purification of ground water or surface water, the level of pathogenic microorganisms and indicator organisms are absent in detectable levels in treated drinking water. To ensure that microbial safety of drinking water is maintained during distribution, the two most important control measures are the physical integrity of the distribution system and a continuously high water-pressure. These measures combined prevent the intrusion of contaminated water carrying pathogenic microorganisms in the distribution system. If these two requirements are not met, a chlorine residual in the distribution system may protect the drinking water to some extent to intrusion of microorganisms. The drinking water in the Netherlands is distributed without a chlorine disinfection residual, which requires extra vigilance during repair works or incidents. If small cracks are present and the water pressure is reduced, for example due to a pipe break or pressure transients, ground water may leak into the distribution system [1]. During repair works or incidents contamination may occur as well, despite the hygienic procedures that are in place. Sewage and drinking water pipes are often present in the underground and are close to each other. For that reason the soil and ground 
water next to drinking water pipes contain high numbers of microorganisms (median values): fecal coliforms $\left(2-59 \times 10^{1} \mathrm{MPN} / 100 \mathrm{~mL}, 2 \times 10^{1}-1 \times 10^{2} \mathrm{MPN} / 100 \mathrm{~g}\right)$, Clostridium perfringens $\left(5 \times 10^{1}-1 \times\right.$ $\left.10^{3} \mathrm{cfu} / 100 \mathrm{~mL} ; 1 \times 10^{1}-1 \times 10^{3} \mathrm{cfu} / 100 \mathrm{~g}\right)$, Bacillus subtilis $\left(1.3 \times 10^{6} \mathrm{cfu} / 100 \mathrm{~mL} ; 1.3 \times 10^{8} \mathrm{cfu} / 100 \mathrm{~g}\right)$ and coliphages $\left(1 \times 10^{4} \mathrm{pfu} / 100 \mathrm{~mL}\right.$; absent in soil) [1,2]. Intrusion of ground water into the distribution system may thus lead to contamination of the drinking water and distribution system with enteric pathogens. Even intrusion of a small volume into the distribution system may be of concern as several enteric pathogens are highly infectious [3,4].

Several studies have shown that incidents or repair works of the drinking water distribution system are associated with an elevated risk of gastrointestinal diseases. A cohort study in Norway among households downstream of a main break or maintenance works were compared to unexposed households and showed that exposed households reported 1.58 times more gastrointestinal illnesses [5]. A cohort study in Sweden showed that households were 2.0 times as likely to report vomiting complaints and 1.9 times as likely to report acute gastrointestinal illness after a pipe break or works on the distribution system [6]. Risk factors were identified and included the presence of sewage pipelines at the same level as drinking water pipelines in the trench. Flushing was also associated with an elevated risk, leading to the conclusion that current safety measures might not be sufficient in eliminating the risk of gastrointestinal diseases. Households in Canada consuming tap water reported $19 \%$ to $34 \%$ more gastrointestinal illnesses compared to households receiving water bottled directly at the production plant or receiving tap water treated with reverse osmosis or receiving spring water $[7,8]$. In addition, in a Swedish study routinely available data on the incidence of Campylobacter was used and shown to be positively associated with the average water-pipe length per person suggesting contamination of the water during distribution [9]. Both studies suggest that during distribution the water was contaminated with pathogens, although the distribution systems did meet the microbiological standards (monitoring of indicator bacteria). In contrast, no proof was found for contamination during distribution in two blinded studies: no difference was found for the risk of waterborne gastroenteritis between households in Melbourne [10] or Iowa [11] using a real or sham water treatment unit installed in the kitchen. In a systematic review, a significant association between gastrointestinal disease and tap water versus point of use treated tap water was found for non-blinded studies. However these differences disappeared when only blinded studies were included [12].

To estimate the potential health impacts of contamination of the drinking water distribution system, the QMRA (Quantitative Microbial Risk Assessment) approach was applied [13-16]. A QMRA of negative pressure transients showed that the health risk was mainly affected by the duration of a negative pressure event $[14,15]$ and by the number of nodes drawing negative pressure. The concentration of the contaminant, in both studies Norovirus was used, was not critical, probably due to the high infectivity of the virus [3]. In a QMRA of the health impact of contamination during repair works, the concentration of the contaminant, the time of day the valves are opened after repairs, and the time of consumption were the most important parameters $[17,18]$. Additionally, the type of pathogen and its specific dose-response relationship highly impacts the resulting infection risk [18]. For example, ingestion of roughly 10-100x higher numbers of bacteria compared to protozoa, or 100-1000 $\times$ higher compared to viruses, are required to become infected [19-21]. Together these studies suggest a (potential) role for the loss of physical integrity, pipe breaks and repair works of the drinking water distribution system in the transmission of gastrointestinal diseases.

Flushing and, in case of a persistent microbial contamination in the distribution system, shock chlorination are often used to clean the distribution system after maintenance work or pipe breaks. However, to our knowledge, only limited research has been performed to test the efficacy of flushing and shock chlorination on microorganisms in water and pipe wall biofilm. Flushing experiments in a pilot distribution system used sand particles with a diameter of $0.25-4 \mathrm{~mm}$ and showed that a threshold velocity of $0.8-0.9 \mathrm{~m} / \mathrm{s}$ was required to achieve efficient removal [22]. In the same study the results were extrapolated to the removal of microorganisms. Chlorination was tested in a batch reactor, in which the microorganisms were present in the water but not in a biofilm. Flushing $(0.8 \mathrm{~m} / \mathrm{s})$ 
does not remove Bacillus subtilis from the biofilm of a cement-lined ductile iron pipe, whereas shock chlorination $(200 \mathrm{mg} / \mathrm{L}, 2 \mathrm{~h})$ in the same pilot distribution system led to a modest 1.2-1.4 log removal from the biofilm [23]. However, removal from the water was not tested.

After cleaning the distribution system using flushing or chlorination, drinking water companies want to put the distribution system back into service as quickly as possible. Current practice is that the cleaned area can be put back into service after the monitoring of the water for the fecal indicators E. coli and enterococci shows that these are absent. To ensure the safety of the consumers and to be able to restore normal water distribution, it is important that monitoring can be performed quickly after the cleaning regime is finished and that monitoring is optimized in such a way that the probability of detecting fecal indicators (if present) is as high as possible. Currently, a sample is taken from a convenient tap in the vicinity of the cleaned network, but information about the impact of time and place of sampling on the probability of picking up residual fecal indicators is lacking.

In this paper we used a model pipe-loop system, in which a biofilm was cultured, to study (i) the influence of the waiting time between flushing of the system and sampling the water and (ii) the effect of the distance between sampling point and point of contamination. This knowledge is used to underpin the sampling strategy after flushing in which the waiting time should be as short as possible without decreasing the probability of detecting the fecal indicators. We extend the knowledge on the efficacy of flushing and shock chlorination in removal of a microbial contamination from drinking water pipes. Both flushing and shock chlorination were tested in a model pipe-loop system containing pipes with a cultured biofilm or pipes with an old and natural biofilm that were excavated from the drinking water distribution system. Flushing was tested using several conditions (flushing velocity and flushed water volume) and chlorination was tested for several time periods. Following this, we describe the application of these results to real-life situations.

\section{Materials and Methods}

Experiments were carried out with Escherichia coli (E. coli WR1, NCTC 13167), Enterococcus faecium (E. faecium WR63, NCTC 13169), Clostridium perfringens (C. perfringens D10, NCTC 13170) spores, somatic coliphage phiX174 (ATCC 13706-B1) and bacteriophage MS2 (ATCC 15597-B1). E. coli is the most commonly studied microorganism and also the one most often used as a bacterial indicator of fecal pollution in drinking water. Bacteriophages are used in this study as an alternative for enteric viruses, due to their match in morphology and biological properties [24]. The efficacy of chlorine disinfection of the distribution system depends on several factors including the chlorine concentration, contact time and the type of microorganism. Therefore several types of microorganisms were selected representing bacteria (E. coli), bacterial spores (C. perfringens spores) and viruses (the bacteriophage phiX174), and also representing a spectrum of chlorine-sensitivity, from sensitive (E. coli) to insensitive (spores of C. perfringens). For analysis of the optimal sampling strategy, the fecal indicator bacteria E. coli and enterococci were used. These two indicators are routinely monitored and monitoring is compulsory after works in the distribution system. A water sample of $100 \mathrm{~mL}$ should be negative for both bacteria.

E. coli and Enterococcus faecium used to test the optimal sampling strategy (experiments A1-A4, Table 1), were grown in mineral medium supplied with glucose and potassium nitrate, respectively glucose and brain heart infusion broth. Growth at $22^{\circ} \mathrm{C}$ was monitored by streak-plating on Lab Lemco Agar (LLA) plates. When the maximum colony count was reached the bacterial suspensions were stored at $4{ }^{\circ} \mathrm{C}$ until use. One suspension of each bacterium was prepared and used in all experiments. Shortly before each experiment the colony counts were determined on a specific medium: Laurylsulphate agar (LSA) for E. coli and Slanetz and Bartley agar (S\&B) for Enterococcus faecium. The E. coli colony counts were determined according to NEN-EN-ISO 9308-1 using membrane filtration (0.45 $\mu \mathrm{m}$ pore size), or streak-plating of the sample on LSA-agar plates. Agar plates were incubated for $5 \mathrm{~h}$ at $25^{\circ} \mathrm{C}$ followed by $14 \mathrm{~h}$ at $36^{\circ} \mathrm{C}$. The Enterococcus faecium colony counts were determined on S\&B agar for $48 \mathrm{~h}$ at $36{ }^{\circ} \mathrm{C}$, according to NEN-EN-ISO 7899-2. MS2 F-specific bacteriophages were purchased via GAP 
EnviroMicrobial Services. The number of MS2 was determined according to the double-agar layer method in NEN-ISO 10705-1. In short, decimal dilutions of the sample containing MS2 was mixed with the host bacterium Salmonella typhimurium WG49 in log-phase and semi-solid Tryptone-Yeast Extract-Glucose agar. The mixture was immediately spread on an agar plate and allowed to solidify. Incubation was performed at $36{ }^{\circ} \mathrm{C}$ for $24 \mathrm{~h}$. The heterotrophic plate count (HPC) was determined according to NEN-EN-ISO 6222. The sample is mixed with dissolved plate count agar solution and poured into a petri dish. The sample is incubated at $22^{\circ} \mathrm{C}$ for $68 \mathrm{~h}$.

Table 1. Flushing conditions to determine the optimal sampling strategy.

\begin{tabular}{cccccc}
\hline & Contamination & E. coli & Enterococci & MS2 & \multirow{2}{*}{ Flushing } \\
\cline { 3 - 5 } & & Total cfu & Total cfu & Total pfu & \\
\hline A1 & Water & $1.2 \times 10^{10}$ & $8.1 \times 10^{8}$ & $1.3 \times 10^{11}$ & $1.27 \mathrm{~m} / \mathrm{s}, 2.5$ vol \\
A2 & Water & $5.3 \times 10^{9}$ & $4.0 \times 10^{8}$ & $9.7 \times 10^{10}$ & $1.27 \mathrm{~m} / \mathrm{s}, 2.5$ vol \\
A3 & Sand and Water & $1.1 \times 10^{10}$ & $2.6 \times 10^{8}$ & $1.7 \times 10^{11}$ & $1.27 \mathrm{~m} / \mathrm{s}, 2.5 \mathrm{vol}$ \\
A4 & Water & $2.6 \times 10^{10}$ & $7.4 \times 10^{8}$ & $1.0 \times 10^{11}$ & $0.45 \mathrm{~m} / \mathrm{s}, 0.9$ vol \\
\hline
\end{tabular}

For the flushing and chlorination experiments (experiments B1-B5 and C1-C3, Tables 2 and 3), E. coli bacteria were grown in Lab Lemco Broth (LLB) for $72 \mathrm{~h}$ at $36^{\circ} \mathrm{C}$. Growth medium was removed by washing the bacteria three times in sterile tap water. The number of $E$. coli bacteria in the suspension was determined on LSA agar plates as described above. For each experiment the bacteria were freshly prepared. C. perfringens D10 was cultured on Perfringens agar base (PAB), after which the colonies were aseptically transferred to sterile tap water. To induce sporulation of the bacteria, the bacteria were incubated for two weeks at $36{ }^{\circ} \mathrm{C}$ after which the spores were stored at $4{ }^{\circ} \mathrm{C}$. One spore suspension was prepared and used for all experiments. A few days before each experiment the number of spores in the suspension was determined according to NEN-ISO 6461. In short, prior to enumeration the sample was heated at $60{ }^{\circ} \mathrm{C}$ for $30 \mathrm{~min}$ to kill vegetative bacteria. The colony count was determined using membrane filtration or streak-plating on PAB agar plates at $36^{\circ} \mathrm{C}$ for 24 to $48 \mathrm{~h}$. phiX174 somatic coliphages were grown by infection of an E. coli WG5 culture with phiX174 for $5 \mathrm{~h}$ at $36^{\circ} \mathrm{C}$. The growth medium was removed by centrifugation and ultrafiltration. One suspension of phiX174 coliphages was prepared and used for all experiments. A few days before each experiment the number of phiX174 in the suspension was determined according to NEN-ISO 10705-2. The sample was mixed with E. coli WG5 in log-phase and semi-solid Modified Scholtens Agar, spread immediately on an agar plate and allowed to solidify. Incubation was performed at $36^{\circ} \mathrm{C}$ for $24 \mathrm{~h}$.

Table 2. Conditions to determine the efficacy of flushing and chlorination on the removal microorganisms from the water and biofilm.

\begin{tabular}{|c|c|c|c|c|c|c|c|c|}
\hline & \multicolumn{2}{|c|}{ E. coli } & \multicolumn{2}{|c|}{ Clostridium D10 } & \multicolumn{2}{|c|}{ phiX174 } & \multirow{2}{*}{ Flushing } & \multirow{2}{*}{$\begin{array}{c}\text { Free } \\
\text { Chlorine }\end{array}$} \\
\hline & Total cfu & $\mathrm{cfu} / \mathrm{mL}$ & Total cfu & $\mathrm{cfu} / \mathrm{mL}$ & Total pfu & $\mathrm{pfu} / \mathrm{mL}$ & & \\
\hline B1 & $7.5 \times 10^{10}$ & $9.4 \times 10^{5}$ & $2.6 \times 10^{8}$ & $3.3 \times 10^{3}$ & - & - & $1.5 \mathrm{~m} / \mathrm{s}, 3 \mathrm{vol}$ & $\begin{array}{c}10 \mathrm{mg} / \mathrm{L} \\
0-24 \mathrm{~h}\end{array}$ \\
\hline B2 & $6.3 \times 10^{10}$ & $5.7 \times 10^{5}$ & $8.4 \times 10^{8}$ & $7.6 \times 10^{3}$ & $1.0 \times 10^{11}$ & $9.1 \times 10^{5}$ & $1.5 \mathrm{~m} / \mathrm{s}, 3 \mathrm{vol}$ & $\begin{array}{c}10.5 \mathrm{mg} / \mathrm{L}, \\
0-24 \mathrm{~h}\end{array}$ \\
\hline B3 & $7.9 \times 10^{10}$ & $7.2 \times 10^{5}$ & $2.0 \times 10^{9}$ & $1.8 \times 10^{4}$ & $5.4 \times 10^{10}$ & $5.0 \times 10^{5}$ & $1.0 \mathrm{~m} / \mathrm{s}, 3 \mathrm{vol}$ & - \\
\hline B4 & $7.5 \times 10^{11}$ & $6.8 \times 10^{6}$ & $3.4 \times 10^{8}$ & $3.1 \times 10^{3}$ & $9.4 \times 10^{10}$ & $8.5 \times 10^{5}$ & $\begin{array}{c}0.3 \mathrm{~m} / \mathrm{s} \\
3-6-10-15 \text { vol }\end{array}$ & $\begin{array}{c}10 \mathrm{mg} / \mathrm{L} \\
0-24 \mathrm{~h}\end{array}$ \\
\hline B5 & $5.2 \times 10^{8}$ & $5.7 \times 10^{10}$ & $1.5 \times 10^{7}$ & $1.7 \times 10^{9}$ & $4.0 \times 10^{8}$ & $4.4 \times 10^{10}$ & $\begin{array}{c}0.3 \mathrm{~m} / \mathrm{s} \\
3-6-10-15 \text { vol; } \\
1.5 \mathrm{~m} / \mathrm{s} \\
3-6-10-15 \text { vol }\end{array}$ & - \\
\hline
\end{tabular}


Table 3. Experimental conditions to determine the efficacy of flushing and chlorination on the removal of microorganisms from the water and biofilm from real-world pipe segments with a natural biofilm.

\begin{tabular}{|c|c|c|c|c|c|c|c|c|}
\hline & \multicolumn{2}{|c|}{ E. coli } & \multicolumn{2}{|c|}{ C. perfringens } & \multicolumn{2}{|c|}{ phiX174 } & \multirow{2}{*}{ Flushing } & \multirow{2}{*}{$\begin{array}{c}\text { Free } \\
\text { Chlorine }\end{array}$} \\
\hline & Total cfu & $\mathrm{cfu} / \mathrm{mL}$ & Total cfu & $\mathrm{cfu} / \mathrm{mL}$ & Total pfu & $\mathrm{pfu} / \mathrm{mL}$ & & \\
\hline $\mathrm{C} 1$ & $5.0 \times 10^{10}$ & $4.5 \times 10^{5}$ & $1.0 \times 10^{9}$ & $9.2 \times 10^{9}$ & $6.7 \times 10^{10}$ & $6.1 \times 10^{5}$ & $1.5 \mathrm{~m} / \mathrm{s}, 3 \mathrm{vol}$ & $\begin{array}{c}10 \mathrm{mg} / \mathrm{L} \\
0-24 \mathrm{~h}\end{array}$ \\
\hline $\mathrm{C} 2$ & $7.5 \times 10^{10}$ & $5.8 \times 10^{5}$ & $3.2 \times 10^{9}$ & $2.9 \times 10^{4}$ & $4.0 \times 10^{10}$ & $3.7 \times 10^{5}$ & $1.5 \mathrm{~m} / \mathrm{s}, 3 \mathrm{vol}$ & $\begin{array}{c}10 \mathrm{mg} / \mathrm{L}, \\
0-24 \mathrm{~h}\end{array}$ \\
\hline $\mathrm{C} 3$ & $1.0 \times 10^{11}$ & $9.5 \times 10^{5}$ & $3.0 \times 10^{9}$ & $2.7 \times 10^{4}$ & $4.7 \times 10^{10}$ & $4.3 \times 10^{5}$ & $\begin{array}{c}0.3 \mathrm{~m} / \mathrm{s} \\
3-6-10-15 \text { vol }\end{array}$ & $\begin{array}{c}10 \mathrm{mg} / \mathrm{L}, \\
0-24 \mathrm{~h}\end{array}$ \\
\hline
\end{tabular}

To determine the adenosine triphosphate (ATP) concentration in the samples luciferin and luciferase were added. In the presence of ATP luciferin is degraded by luciferase during this process light is produced and measured in a luminometer. For measuring the iron concentration the water sample was treated with nitric acid according to NEN-EN-ISO 15587-2:2002. The concentration of the released iron determined using inductively coupled plasma mass spectrometer (ICP-MS).

Analyses of the biofilm were performed by swabbing roughly $7 \mathrm{~cm}$ of pipe wall biofilm (all sides), $1-2 \mathrm{~cm}$ pipe wall biofilm at the start of the pipe segment was not swabbed. For swabbing multiple sterile cotton swabs were used. Of each pipe the swabbed surface area was calculated. The swabs were pooled in $40 \mathrm{~mL}$ sterile tap water and the biomass was released from the swab by low-energy sonification using a Branson Sonifier ultrasonic cell disruptor for $2 \mathrm{~min}$ at 40-kHz and 90-Watt power output (equivalent to $45 \%$ amplitude). During sonification the mixture was kept on ice. In the resulting water sample the required parameters were determined.

Die-off kinetics of all microorganisms were determined in tap water to which a concentration of microorganisms was added in similar concentrations as to the pipe-loop system. The water was incubated for $24-72 \mathrm{~h}$ at $22{ }^{\circ} \mathrm{C}$, the number of microorganisms was determined several times during this period.

In some of the experiments an artificial biofilm was cultured in the pipe-loop system prior to the experiment. To achieve a reproducible biofilm acetate $\left(\mathrm{NaCH}_{3} \mathrm{COO}, 10 \mu \mathrm{g} \mathrm{C} / \mathrm{L}\right)$, nitrate $\left(\mathrm{KNO}_{3}, 2 \mu \mathrm{g}\right.$ $\mathrm{N} / \mathrm{L})$ and phosphate $\left(\mathrm{KH}_{2} \mathrm{PO}_{4}, 0.1 \mu \mathrm{g} \mathrm{P} / \mathrm{L}\right)$ were added to the water. After continuous circulation of the water at $0.1 \mathrm{~m} / \mathrm{s}$ in the pilot system for two weeks the biofilm and water were analyzed for ATP and HPC. The system was drained and flushed on low speed to remove remaining nutrients before starting the experiment.

Three slightly different model pipe-loop systems were built (Figure 1). All systems were $20 \mathrm{~m}$ long and consisted of PVC-pipes with an outer diameter of $63 \mathrm{~mm}$ and inner diameter of $55 \mathrm{~mm}$. At several points along the $20 \mathrm{~m}$-system taps for water sampling were placed. A flow meter was placed immediately after the flushing pump. After each experiment the biofilm was removed from the complete system by flushing with a SDS solution, tap water, citric acid solution and tap water. In addition, the long stretches of pipe were replaced with new pipes. Depending on the specific research questions, small alterations were made to the pipe-loop system, as described below. 


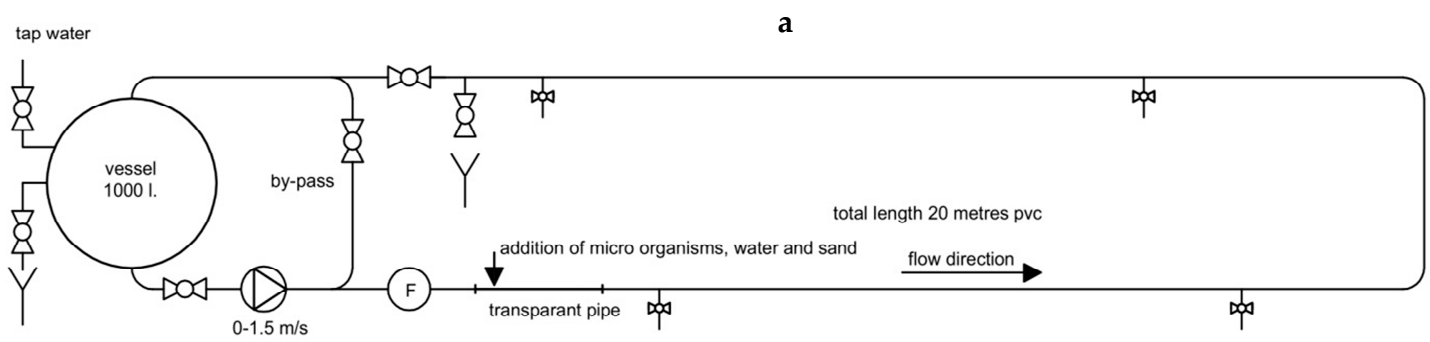

b

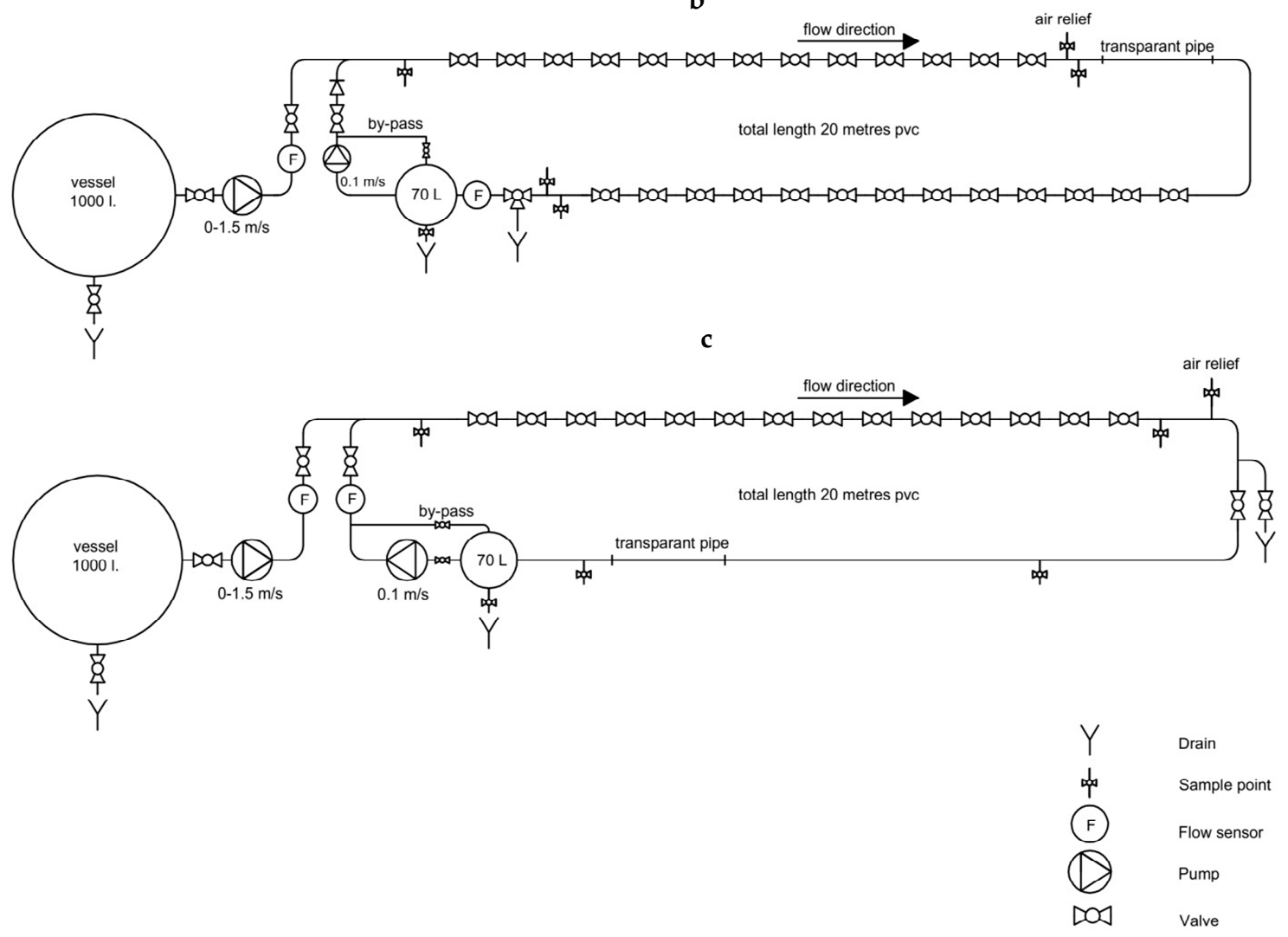

Figure 1. Schematic overview of the pipe-loop distribution systems that were used for experiments A1-A4 (a), B1-B3 (b) and B4, B5, C1-C3 (c). In systems B and C pipe segments were placed between valves that were replaced with new segments to sample the biofilm.

For determining the optimal sampling strategy (experiments A1-A4), the system in Figure 1a was used. Sampling taps were placed after 1, 5, 10 and $20 \mathrm{~m}$. For all experiments a biofilm was cultured. Next, the system was drained and artificially contaminated water or sand was added to the system immediately after the flushing pump and flow meter. The contaminated water or sand was left in the drained pipe for one hour to allow the microorganisms to attach to the biofilm. Flushing was performed according to Table 1 . This procedure was chosen to mimic repair works on the distribution system as much as possible (i.e., the opening of a drained pipe and contaminated water or sand that may enter and reside for some time in the pipe before flushing is started). After flushing the system was closed, without any circulation or flow of the water to mimic the withholding time of the water in the pipe before the sample is taken, and water samples were taken after 1, 2, 6 and $24 \mathrm{~h}$ at the four sampling taps. At the end of the experiment the system was drained and the biofilm was sampled at 1 , 10 , and $20 \mathrm{~m}$ to determine the amount of microorganisms present in the biofilm. The efficacy of the several flushing regimes on this pipe-loop system was compared by calculating a mass balance. It was assumed that before flushing all microorganisms were present in the water and were absent from the 
biofilm. Numbers found in the water and biofilm samples $24 \mathrm{~h}$ after flushing were extrapolated to the entire water phase and pipe wall. Using these numbers the log removal of the microorganisms was calculated.

To determine to efficacy of flushing and chlorination on removal of microorganisms from water and biofilm (experiments B1-B5), the system in Figure $1 \mathrm{~b}$ was used. A large number of removable pipe segments were included with ball valves on both sides. Individual segments could be taken out for analyses and replaced by a new segment, without loss of water or the need to drain the system. A small circulation reservoir, circulation pump, and flow meter were included in the system. During the entire experiment the water was circulated with $0.1 \mathrm{~m} / \mathrm{s}$ (the average flow in the Dutch distribution system) using the circulation pump. For all experiments a biofilm was cultured. Microorganisms were added to the water and circulated for $24 \mathrm{~h}$ before the system was flushed according to Table 2. Only the pipes between the flushing pump and the drain to the sewage system were flushed. The parts necessary for circulation (pump, reservoir, flow meter) were blocked by closed valves. After flushing, samples were taken and the water in the entire system was circulated for $30 \mathrm{~min}$ to ensure mixing of microorganisms throughout the water phase. Shock chlorination was started by addition of concentrated sodium hypochlorite to the circulation reservoir up to a concentration of $10 \mathrm{mg} / \mathrm{L}$ in the water of the entire system. The free chlorine concentration was measured after $20 \mathrm{~min}, 1-3-6-24 \mathrm{~h}$ (Hach, LCK310). During the flushing and chlorination procedures the water and biofilm were sampled at different time points, depending on the experiment: after 3-6-10-15 flushing volumes (the volume of the pipe segment that is flushed, i.e., 3 flushing volumes implies that the volume of the pipe segment was replaced three times) and after 1, 6 and $24 \mathrm{~h}$ contact time with chlorine.

To test the efficacy of flushing and chlorination on real-world pipes (PVC) with a natural biofilm (experiments $\mathrm{C} 1-\mathrm{C} 3$ ), the system of Figure $1 \mathrm{~b}$ was adapted in such a way that pipes excavated from a distribution system could be incorporated in the pipe-loop system. The pipes were derived from different Dutch drinking water companies and were 35, 51, and 27 years old. Five meters of pipe, in segments of $50 \mathrm{~cm}$, were excavated under hygienic procedures. The segments were closed with a cap and packaged in plastic bags, transported at $4{ }^{\circ} \mathrm{C}$ to the laboratory and incorporated within $6 \mathrm{~h}$ in the pilot distribution system. Before incorporation the sawdust was gently removed and the segments were incorporated using the same orientation (flow direction and up and bottom side of the pipe) as in the distribution system. Only the incorporated part was flushed (Figure 1c). No biofilm was grown in the remaining $15 \mathrm{~m}$ pipe that were not flushed, to ensure that only the effect of a natural biofilm was monitored. After incorporation of the real-world pipe segments in the system, the system was circulated for 4 days with location-specific drinking water. After 4 days the water was refreshed, microorganisms were added and circulated for $24 \mathrm{~h}$ at $0.1 \mathrm{~m} / \mathrm{s}$. Flushing and chlorination were performed as described above (Table 3).

\section{Results and Discussion}

\subsection{Growth or Decay of Microorganisms in Pipe-Loop System}

During the experiments with the pipe-loop systems, the microorganisms are present in the pipe-loop system for 24 to $48 \mathrm{~h}$ which may induce growth or die-off of the microorganisms. To ensure that an increase or decrease in the number of microorganisms can be attributed to flushing, chlorination, attachment to or release from the biofilm, and is not due to decay (or growth) within this time frame, die-off kinetics of all microorganisms in water were determined (Figure 2). MS2 and enterococci remained stable for at least $24 \mathrm{~h}$, the number of E. coli, C. perfringens and phiX174 also remained stable for $72 \mathrm{~h}$. Therefore, any changes in the number of microorganisms in the pipe-loop system experiments can be attributed to flushing, chlorination, or attachment to or release from the biofilm. 


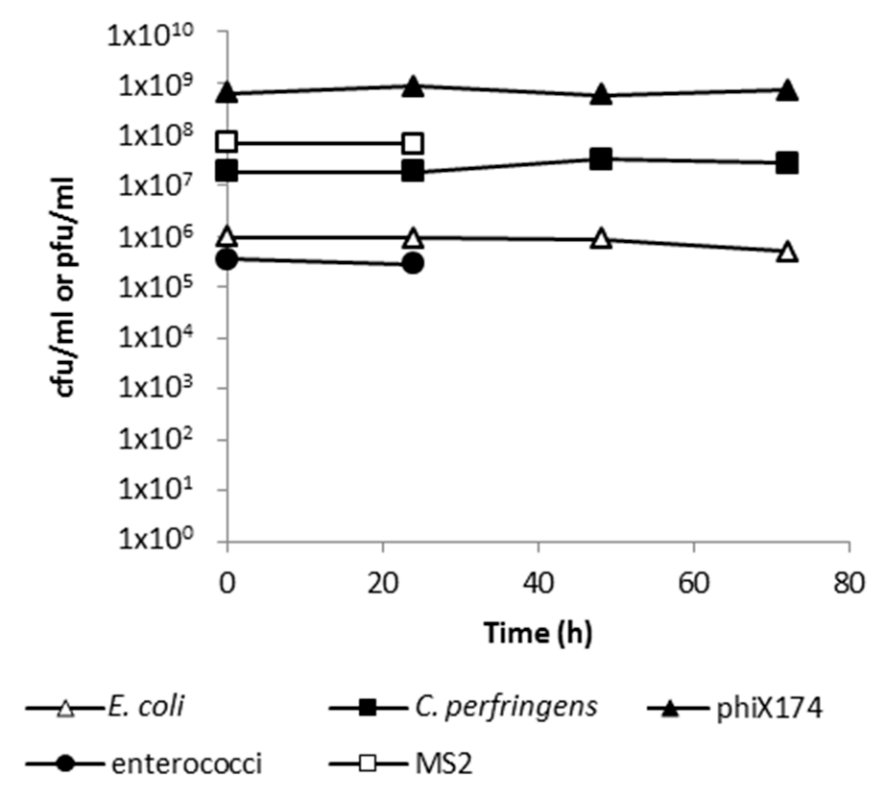

Figure 2. Die-off curves of micro-organisms in water for 24-72 h.

\subsection{Biofilm Characteristics}

During all experiments, a biofilm was present in the pipe-loop system, either a biofilm was cultured or real-world pipe segments with a natural biofilm were incorporated in the system. Just before the start of each experiment, the water in the pipe-loop system and the biofilm were analyzed for HPC, ATP and iron. Previous studies mention different HPC numbers for a representative, living biofilm: $10^{4}-10^{5} \mathrm{cfu} / \mathrm{mL}$ in water and $10^{4}-10^{5} \mathrm{cfu} / \mathrm{cm}^{2}$ for a cultured biofilm (USEPA, 2008) and $10^{1}-10^{6} \mathrm{cfu} / \mathrm{cm}^{2}$ for established biofilms $[25,26]$. The HPC count in the water of the pipe-loop systems with a cultured biofilm falls within this range $\left(5.9 \times 10^{4} \mathrm{cfu} / \mathrm{mL}\right)$, the biofilm yields slightly higher HPC numbers $\left(3.1 \times 10^{5} \mathrm{cfu} / \mathrm{cm}^{2}\right.$; Figure 3A). ATP counts were high $\left(2.8 \times 10^{4} \mathrm{pg} / \mathrm{mL}\right.$ and $\left.2.9 \times 10^{4} \mathrm{pg} / \mathrm{cm}^{2}\right)$, indicating a large active biomass population and a very low amount of iron was present $\left(0.23 \mu \mathrm{g} / \mathrm{cm}^{2}\right)$. The low iron concentration shows that within two weeks a microbiological representative and living biofilm can be cultured, but accumulation of iron in the biofilm is very limited. The excavated pipes from the distribution system with a natural biofilm showed lower HPC counts and ATP concentrations than the cultured biofilms ('Entry' in Figure 3B): $16.7 \mathrm{cfu} \mathrm{HPC} / \mathrm{mL}$ and $3.97 \mathrm{pg}$ ATP/mL in the water and $40.2 \mathrm{cfu} \mathrm{HPC} / \mathrm{mL}$ and $227 \mathrm{pg} \mathrm{ATP} / \mathrm{cm}^{2}$ in the biofilms. The iron concentration was much higher $\left(7.5 \mu \mathrm{g} / \mathrm{cm}^{2}\right)$ and clearly visible by eye. After four days of circulation with drinking water, the HPC number had increased with 3.2-4.8 logs and the ATP concentration with 0.7-1.6 log. The iron and TOC levels remained stable at $5.4-7.0 \mu \mathrm{g} / \mathrm{cm}^{2}$ respectively $0.01 \mathrm{mg} \mathrm{C} / \mathrm{cm}^{2}$.

\subsection{Flushing with $1.27 \mathrm{~m} / \mathrm{s}$}

To test the optimal sampling strategy after flushing several contamination scenarios were simulated in the pipe-loop system (Figure 1a, Table 2). Flushing according to the guidelines (1.27 m/s, 2.5 volumes) removed 2.7-3.4 log E. coli, 3.5-4.2 log enterococci and 3.5-3.9 log MS2 from the water (Figure 4A, experiments A1 and A2). Microorganisms in sand and water were removed to a comparable extent (A3). Flushing with suboptimal velocity $(0.45 \mathrm{~m} / \mathrm{s})$ and replacing the water with only 0.9 volumes is much less efficient (experiment A4). Until now it was generally assumed that flushing a distribution system with a clean water front removes all contaminants such as sediment and microorganisms. Although a large part of the microorganisms was removed, the results show that the pipe-loop system was not entirely clean and microorganisms remained in both water and biofilm, despite the high flushing speed and volumes that were used. 
A

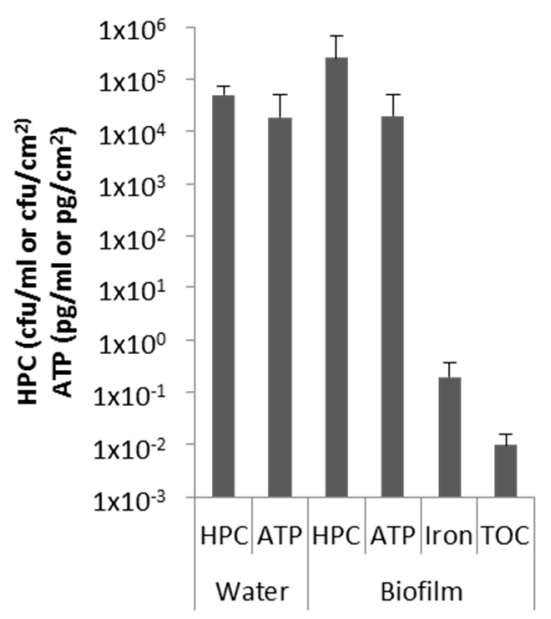

B

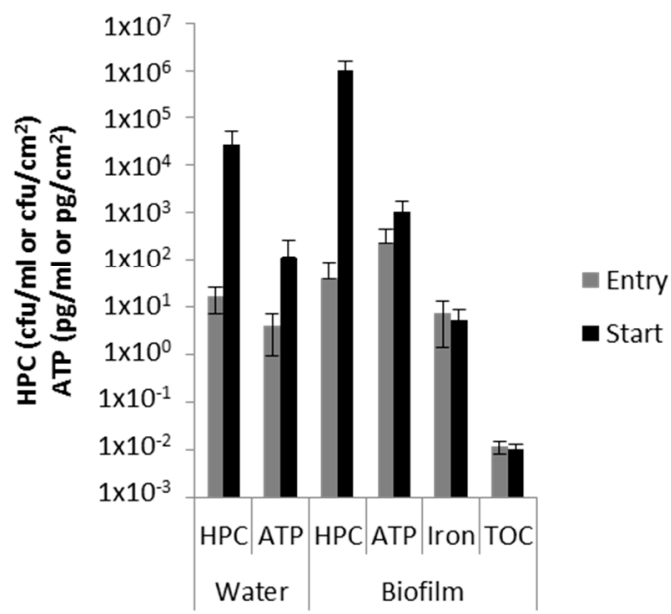

Figure 3. Average (with standard deviation (SD)) of heterotrophic plate count (HPC) number, adenosine triphosphate (ATP) and iron concentration of the cultured biofilm after 14 days ((A), n = 2-5) and, including TOC levels, of natural biofilms upon arrival at the laboratory (entry) and immediately before start of the experiment $((\mathbf{B}), \mathrm{n}=3)$.
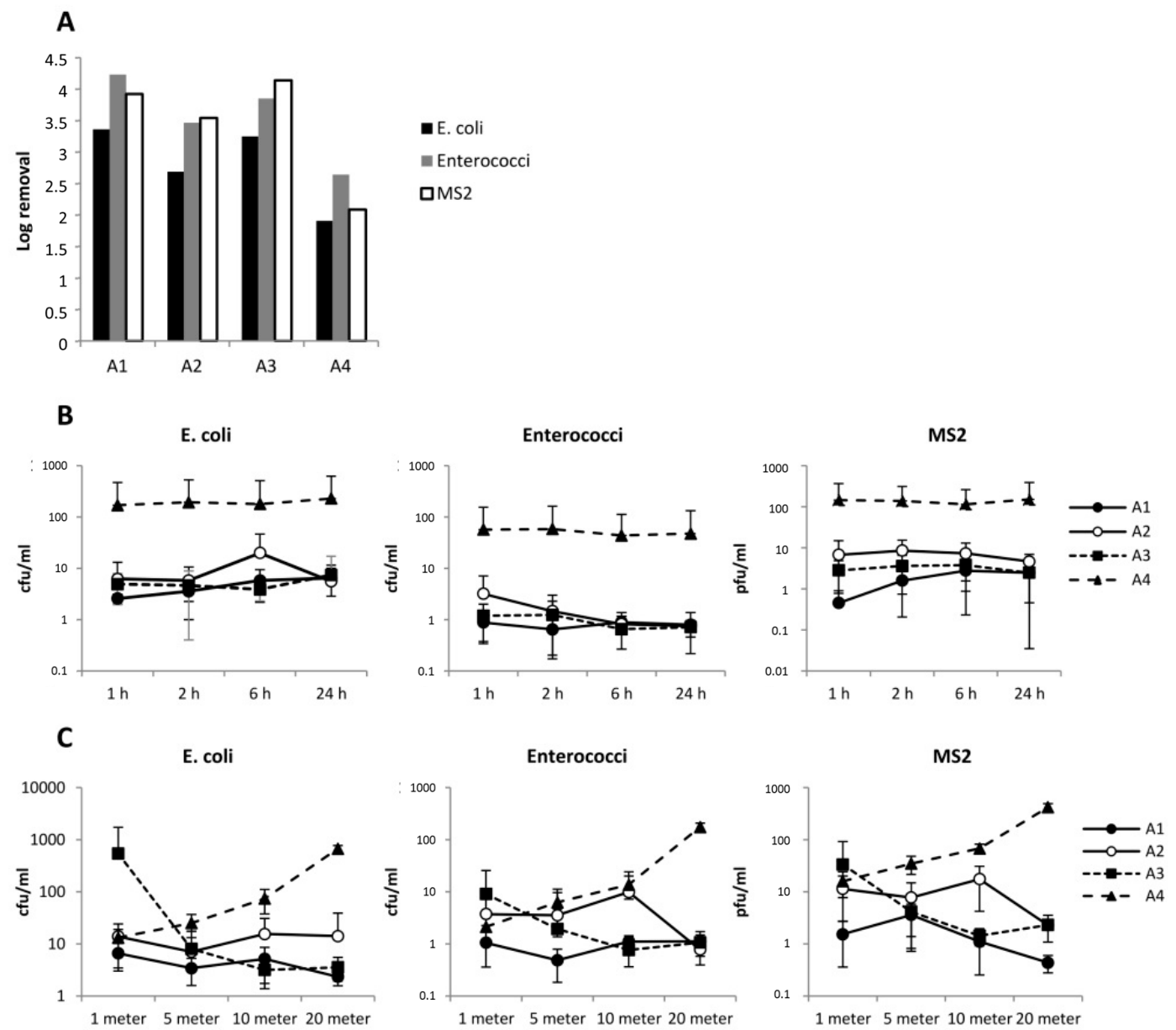

Figure 4. (A). Flushing efficacy (A1-A3: $1.27 \mathrm{~m} / \mathrm{s} ; 2.5$ volumes; A4: $0.45 \mathrm{~m} / \mathrm{s}, 0.9$ volumes) of the individual experiments. (B) Role of waiting time after flushing $(\mathbf{C})$ and distance from the contamination point on the number of microorganisms in the water. Shown is the average, with SD, of the results of four distances per time point (B) or the average of the results of four time points per distance point (C). 


\subsection{Role of Waiting Time between Flushing and Sampling}

After flushing, the pipe-loop system was closed and water remained stagnant for $24 \mathrm{~h}$ during which samples were taken. The number of microorganisms in the water changed very little over time (Figure 4B). Two exceptions showed a decreasing (enterococci in A2) or increasing (MS2 in A1) pattern. This result was only seen once and therefore suggests that this may be variation caused by the large setup of the experiments or might be explained by natural variation. Differences in waiting time between flushing and sampling thus does not appear to affect the number of microorganisms present in the water. The general lack of changes in the number of microorganisms suggests that exchange between water and biofilm is not significant: the number of microorganisms that attaches to or releases from the biofilm is too small to detect in this setup. An alternative explanation could be that the microorganisms in biofilm and water are in equilibrium, with the same number of microorganisms attaching to and releasing from the biofilm. The results indicate that the probability of detecting fecal indicators one hour after flushing is similar to later time points. Hence, in a real situation in which repair works have been performed, followed by flushing, a waiting time longer than one hour before sampling is not necessary, does not change the chance of detecting a microorganism and unnecessarily leads to a longer period during which that particular section of the drinking water distribution system cannot be released for consumption.

After flushing, the water was sampled at different distances along the pipe-loop system to test whether the distance between the point of contamination and sampling point affects the number of microorganisms that were found. When microorganisms were dosed in water and flushing was performed according to the guidelines, the number of microorganisms in water varied little over the distance (Figure 4C; experiment A1 and A2). Exceptions are Enterococcus faecium and MS2 in experiment A2: at $20 \mathrm{~m}$ lower numbers were found than at the 10-m sampling point. Dosage of microorganisms in sand and water in experiment $\mathrm{A} 3$ leads to high numbers close to the contamination point and the number of microorganisms declined with an increasing distance. Especially at the first sampling point at $1 \mathrm{~m}$ high numbers of microorganisms were found, and these numbers declined rapidly with increasing distance. After flushing, the sand was not completely removed and was particularly present in the first few meters after the contamination point, and was most likely the cause of the larger number of microorganisms at 1- and 5-m sampling points. Slower flushing with less volumes yielded the reverse picture, the number of microorganisms increased with the distance (experiment A4). At $1 \mathrm{~m}$ the number was comparable to the other experiments, but at $20 \mathrm{~m}$ the number was about two logs higher. The water in the pipe-loop system was not completely refreshed as flushing was performed with only 0.9 volumes. After flushing the bulk of the contamination has arrived at around the 20-m point where the sample was taken. Whether the less efficient removal is caused by the lower flushing velocity or by lower flushing volume cannot be determined from these experiments. However, the comparable low number of microorganisms at $1 \mathrm{~m}$ between experiments A1, A2 and A4 suggests that the flushing speed is less important.

\subsection{Attachment of Microorganisms to the Biofilm}

In the previous experiments only the flushing efficacy in removing microorganisms from the water was tested. However, in all pipes of the drinking water distribution system a biofilm is present. It may be possible that characteristics of the biofilm influence the attachment of microorganisms and thus the efficacy of flushing and chlorination. Therefore, not only a biofilm was cultured in the pipe-loop system, but also segments of real-world pipes with a natural biofilm were taken from the distribution system and incorporated in the pipe-loop system. Binding of microorganisms to the biofilm, flushing and chlorination were tested in pipe-loop systems with a cultured biofilm (experiments B1-B3, Figure 1b and Table 2) or a natural biofilm (experiments C1-C3, Figure 1c and Table 3).

After addition of the microorganisms to the water in the pipe-loop system, the water was circulated for $24 \mathrm{~h}$ to allow the microorganisms to attach to the biofilm (Table 4). The binding efficacy differed for each microorganism, but was comparable between the cultured and natural biofilm: C. perfringens 
spores bound most efficiently to the biofilm ( $42.3 \%$ and $36.4 \%$, respectively), followed by E. coli (6.7\% and $3.3 \%)$ and phiX174 (0.6\% and $0.7 \%)$. These binding efficiencies are comparable to a previous study using small reactors with glass pearls on which a biofilm was cultured using similar methods as this study. Approximately $10 \%$ of the E. coli bacteria was bound to the biofilm [27]. However, using young, natural, 7-10 months old, drinking water biofilms in a flow chamber only $0.03 \%$ of E. coli was attached [28]. Another study showed a $1 \mathrm{log} / \mathrm{cm}^{2}$ binding of phiX174 (after dosing $5.6 \mathrm{log}$ ) to a natural, 7-month old, biofilm [29], compared to $3-4 \mathrm{log} / \mathrm{cm}^{2}$ in this study. Additionally, in a pilot distribution system spores of the bacterium Bacillus subtilis attached to a cultured biofilm with 3-4 $\mathrm{log} / \mathrm{cm}^{2}$ [23]. Some reasons for the large differences in binding characteristics between the studies might be the environment, the composition of the drinking water and the pipe material that affect biofilm formation. However, within our study we did not find differences between a cultured biofilm and a natural biofilm and when drinking water from different locations was used. A clear explanation for the differences is lacking, however, in all studies the microorganisms bind to the biofilm. These attached microorganisms may negatively affect the efficacy of flushing procedures and the chlorine disinfection.

Table 4. Binding of microorganisms to cultured and natural biofilm.

\begin{tabular}{cccccccc}
\hline & & \multicolumn{2}{c}{ E. coli } & \multicolumn{2}{c}{ C. perfringens } & \multicolumn{2}{c}{ phiX174 } \\
\cline { 3 - 7 } & & Water & Biofilm & Water & Biofilm & Water & Biofilm \\
\hline \multirow{4}{*}{ Cultured } & B1 & 99.7 & 0.3 & 27.0 & 73.0 & - & - \\
biofilm & B2 & 87.5 & 12.5 & 72.6 & 27.4 & 99.3 & 0.7 \\
& B3 & 86.3 & 13.7 & 76.2 & 23.8 & 99.7 & 0.3 \\
& B4 & 93.7 & 6.3 & 28.2 & 71.8 & 98.7 & 1.3 \\
& B5 & 99.2 & 0.8 & 84.4 & 15.6 & 99.9 & 0.1 \\
Natural & Average \pm SD & $93.3 \pm 6.3$ & $6.7 \pm 6.3$ & $57.7 \pm 27.8$ & $42.3 \pm 27.8$ & $99.4 \pm 0.5$ & $0.6 \pm 0.5$ \\
biofilm & C2 & 94.4 & 5.6 & 45.0 & 55.0 & 99.3 & 0.7 \\
& C3 & 99.1 & 0.9 & 91.8 & 8.2 & 99.8 & 0.2 \\
& Average \pm SD & $96.7 \pm 2.4$ & $3.3 \pm 2.4$ & $63.6 \pm 24.9$ & $36.4 \pm 24.9$ & $99.3 \pm 0.5$ & $0.7 \pm 0.5$ \\
\hline
\end{tabular}

Note: SD: Standard deviation.

\subsection{Normal Flushing with $1-1.5 \mathrm{~m} / \mathrm{s}$}

After $24 \mathrm{~h}$ circulation, flushing (1.0-1.5 m/s and 3 volumes) removed 1.2-3.1 log E. coli, 0.5-3.0 $\log$ C. perfringens spores and 2.7-3.3 $\log$ phiX174 from the water in the presence of a cultured biofilm (Figure 5A). Removal of phiX174 from water seemed to be most efficient, although the differences were small. The log removal in experiment B1 was markedly lower compared to the other experiments, the reason for this is not known. Removal of microorganisms attached to a cultured biofilm by flushing was limited: $0.3-1.3 \log$ E. coli, 0-0.9 $\log$ C. perfringens and 0.9-1.4 $\log$ phiX174 were removed. Removal of microorganisms from water and biofilm when pipe segments with a natural, old biofilm were used, was comparable to the experiments with a cultured biofilm (Figure 5B). Removal from the water phase was slightly lower in this case, and relatively constant, despite the differences in biofilm site and age and water quality (1.6-2.6 $\log$ E. coli; 2.0-2.2 $\log$ C. perfringens; $2.6-2.7 \log$ phiX174). Removal of microorganisms from the natural biofilm was also slightly lower: 0.2-1.4 log E. coli; 0.2-0.4 log C. perfringens; $-0.2-0.5 \log$ phiX174. Extended flushing with up to 15 volumes only yielded an extra 0.4-0.7 log removal from the water (Figure 6C). Removal in the first three volumes was largest, after which flushing became less effective. 
A

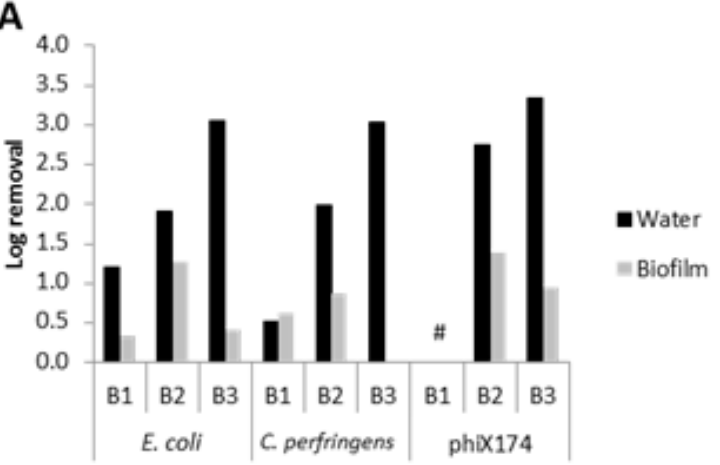

C

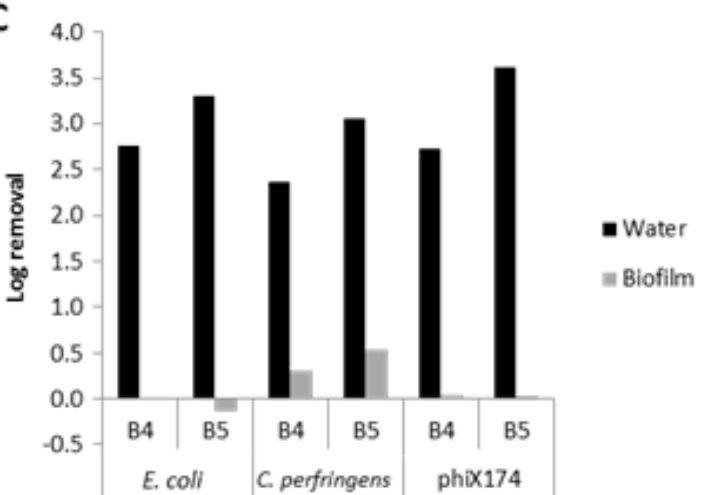

B

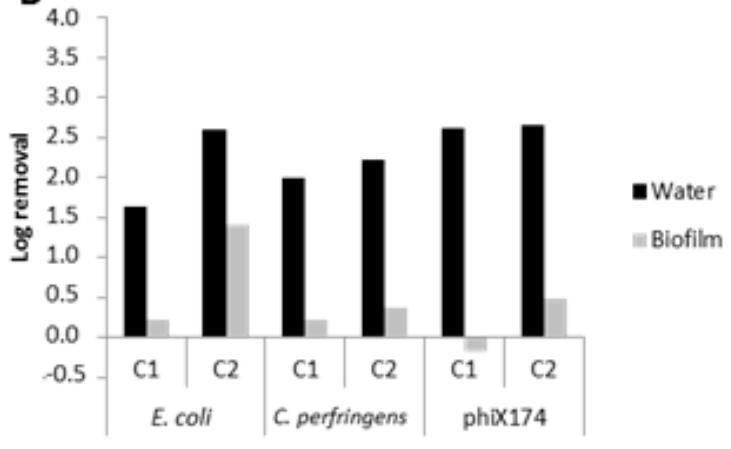

$D_{4}$

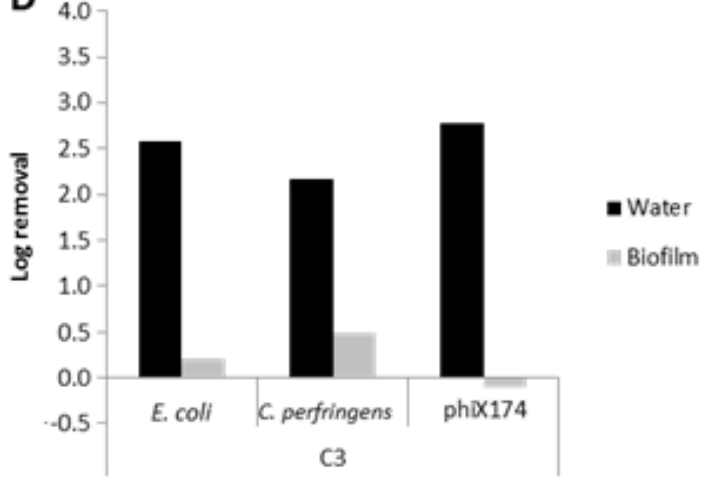

Figure 5. Flushing efficacy in log removal of microorganisms from the water and biofilm of a pipe with a cultured biofilm $(\mathbf{A}, \mathbf{C})$ or a natural biofilm (B,D). In (A) (experiments B1-B3) and (B) (experiments $\mathrm{C} 1-\mathrm{C} 2)$ the pipe-loop system was flushed with 3 volumes at $1.5 \mathrm{~m} / \mathrm{s}$. In (C) (experiment B4-B5) and (D) (experiment C3) the pipe-loop system was flushed with 3 (water) or 15 volumes (biofilm) at $0.3 \mathrm{~m} / \mathrm{s}$. \# phiX174 not added to pipe-loop system and not determined.

\subsection{Slow Flushing with $0.3 \mathrm{~m} / \mathrm{s}$}

Although flushing of the drinking water distribution system should normally be performed at a velocity of $1.5 \mathrm{~m} / \mathrm{s}$ and 3 volumes, this is not always possible due to practical reasons. As mentioned in the AWWA standard C651-14, an alternative can be to flush the distribution system with a lower velocity [30]. In addition, flushing can be extended so more pipe volumes are replaced. However, it is unknown whether this is as efficient as flushing with $1.5 \mathrm{~m} / \mathrm{s}$. Flushing with low speed $(0.3 \mathrm{~m} / \mathrm{s})$ was tested in the pipe-loop system with a cultured (experiments B4-B5) or natural biofilm (experiment C3). Flushing with three volumes at $0.3 \mathrm{~m} / \mathrm{s}$ removed 2.4-2.8 $\log$ microorganisms from the water of a pipe-loop system with a cultured biofilm (Figure 6A). Microorganisms were not removed from the cultured biofilm (0-0.3 log removal). Flushing pipes at low speed with three volumes and a natural biofilm yielded comparable results: $2.2-2.8 \log$ removal of microorganisms from water and $-0.1-0.5 \log$ removal from the biofilm (Figure 6B). Extended flushing with more volumes (up to 15 volumes) at $0.3 \mathrm{~m} / \mathrm{s}$ only yielded an additional 0.2-1.0 log (in the presence of a cultured biofilm) or 0.5-0.9 log (natural biofilm) removal from water (Figure 5C,D). The results show that flushing a pipe-loop system with a cultured or natural biofilm and with a low or high-speed yield comparable results. Flushing removes a large part of the microorganisms from the water, but removal is incomplete. Microorganisms bound to the biofilm are not removed or only to a limited extent. Although a natural and cultured biofilm can have different characteristics, their behavior in flushing experiments is comparable. Results of flushing experiments in a pipe-loop system with a cultured biofilm are thus predictive for results obtained with a natural biofilm. 
A
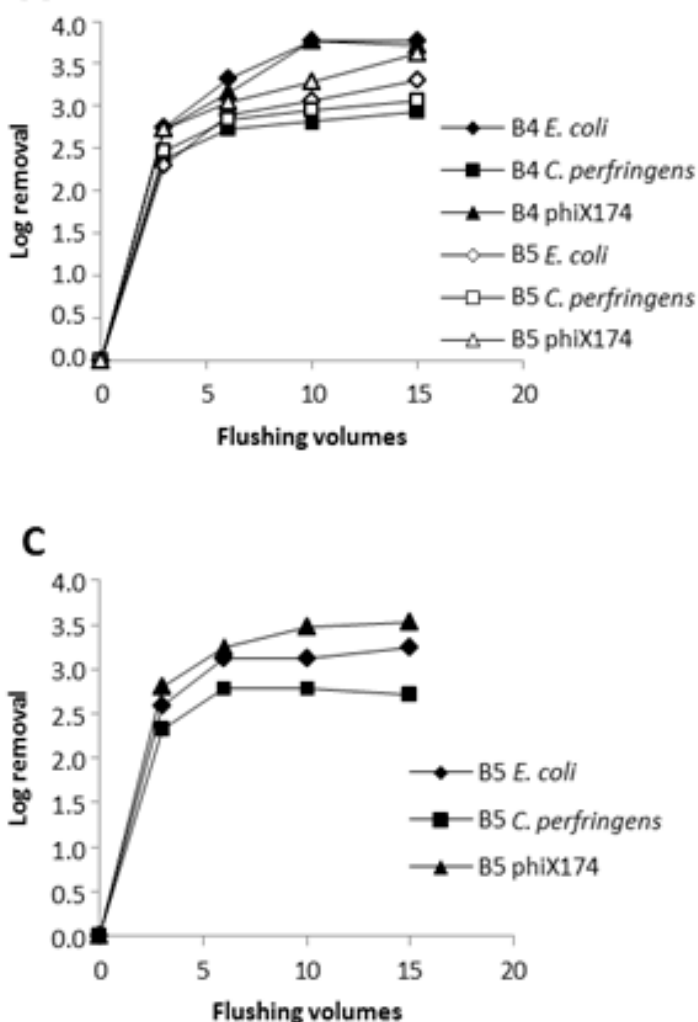

B

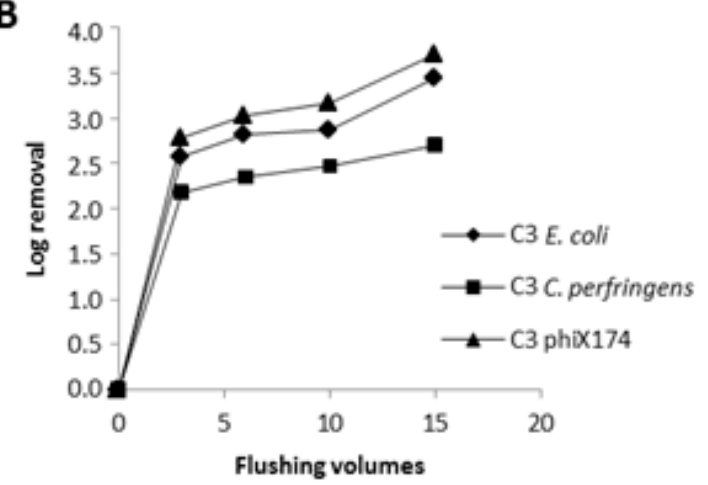

Figure 6. Flushing efficacy in log removal of microorganisms from the water and biofilm of a pipe with a cultured ((A,C); experiments B4 and B5) and natural biofilm ((B); experiment C3). In (A) (experiments B4-B5) and (B) (experiment C3) the pipe-loop system was flushed with 3 volumes (water) or 15 volumes (biofilm) at $0.3 \mathrm{~m} / \mathrm{s}$. In (C) (experiment B5) the pipe loop system was flushed with 15 volumes at $1.5 \mathrm{~m} / \mathrm{s}$. Samples were taken from the water after 3, 6, 10 and 15 volumes without stopping the flushing procedure.

\subsection{Chlorine Disinfection}

Flushing is effective in removing microorganisms from the water, but removal from the biofilm was shown to be very limited. Upon intrusion of (pathogenic) microorganisms in the drinking water distribution system during repairs or low-pressure transients or sites (reservoirs), binding of the microorganisms to the biofilm is likely to occur and, depending on the severity of the contamination, this may involve large numbers. To ensure clean and safe drinking water, intruded microorganisms that have attached to the biofilm have to be removed. Since this study shows that flushing has only very limited effect on the attached microorganisms, one of the possibilities is to combine flushing with shock chlorination, adding a high chlorine concentration (for example $10 \mathrm{mg}$ free chlorine/L) to the drinking water and ensure that the network segment is treated with chlorination. The pipe segment is closed, without consumption and the chlorine is incubated for $24-48 \mathrm{~h}$ to kill off any microorganisms present in water and biofilm. The efficacy of chlorine on microorganisms in water has been studied before in laboratory situations but, to our knowledge, only very limited in a pilot distribution system [23]. The effect of chlorine on microorganisms that are present in or on the biofilm of the pipe wall is assumed to be less effective as the biofilm may protect the microorganisms. To determine the efficacy of chlorination, the flushing procedure was completed and subsequently chlorine was added to the pipe-loop system to a concentration of $10 \mathrm{mg} / \mathrm{L}$ and the chlorinated water was circulated for $24 \mathrm{~h}$. The free chlorine concentration in the water was measured at regular intervals. After $24 \mathrm{~h}$ the chlorine concentration was $6.3-8.6 \mathrm{mg} / \mathrm{L}$.

E. coli is very susceptible to chlorine and the log removal of culturable E. coli in water increases quickly to about $7 \log$ removal (Figure 7). In experiments with a cultured biofilm, the number of E. coli 
in water is below the detection limit after $1 \mathrm{~h}$ of chlorine exposure (CT: $600 \mathrm{mg} \mathrm{min} / \mathrm{L}$ ), experiment $\mathrm{B} 4$ ). In the other two experiments the $E$. coli level in water is below the detection limit after 3.5 (experiment B1) or 6 (experiment B2) hours (CT: 2100-3600 mg min/L; white markings in the graphs of Figure 7). Similar die-off patterns can be seen when real-world pipes with a natural biofilm were incorporated. E. coli was not detectable in the water 1 (experiment C2) to $6 \mathrm{~h}$ (experiment C1 and C3) after dosage of chlorine, corresponding to 7-8 log removal. PhiX174 numbers in water, in the presence of a natural or cultured biofilm, were below the detection limit 1-6 $\mathrm{h}$ after addition of chlorine, corresponding to 7.5 $\log$ removal. C. perfringens spores were more resistant to chlorine and, in water, were still detected in three out of six experiments after $24 \mathrm{~h}$ of chlorination (CT: 14,400 $\mathrm{mg} \mathrm{min} / \mathrm{L}$ ). In the biofilm die-off of all microorganisms was slower than in water. The initial decay upon chlorine dosage was quick, but levels off during the following $24 \mathrm{~h}$. In the cultured biofilm E. coli was most sensitive to chlorine, followed by C. perfringens spores and phiX174. Only at $24 \mathrm{~h}$ the number of microorganisms sometimes dropped below the detection limit, but in most cases the microorganisms were still present in low numbers. In the natural biofilm die-off of microorganisms was slightly faster for E. coli and C. perfringens, but much faster for phiX174. Often the microorganisms cannot be detected after $1 \mathrm{~h}$ (E. coli) or 1-6 $\mathrm{h}$ (phiX174) of chlorination. C. perfringens remained present in two out of three experiments during the $24 \mathrm{~h}$ of chlorine exposure and were most resistant to chlorine. The initial decay upon chlorine dosage was quick, but levels off after $1 \mathrm{~h}$ and hardly any extra $C$. perfringens spores were inactivated. In most experiments the spores were still culturable after $24 \mathrm{~h}$ chlorine exposure. This suggests that a part of the C. perfringens spore population was quite sensitive to chlorine and were inactivated within one hour. The remaining population was more resistant and only a very limited effect of chlorine was visible.

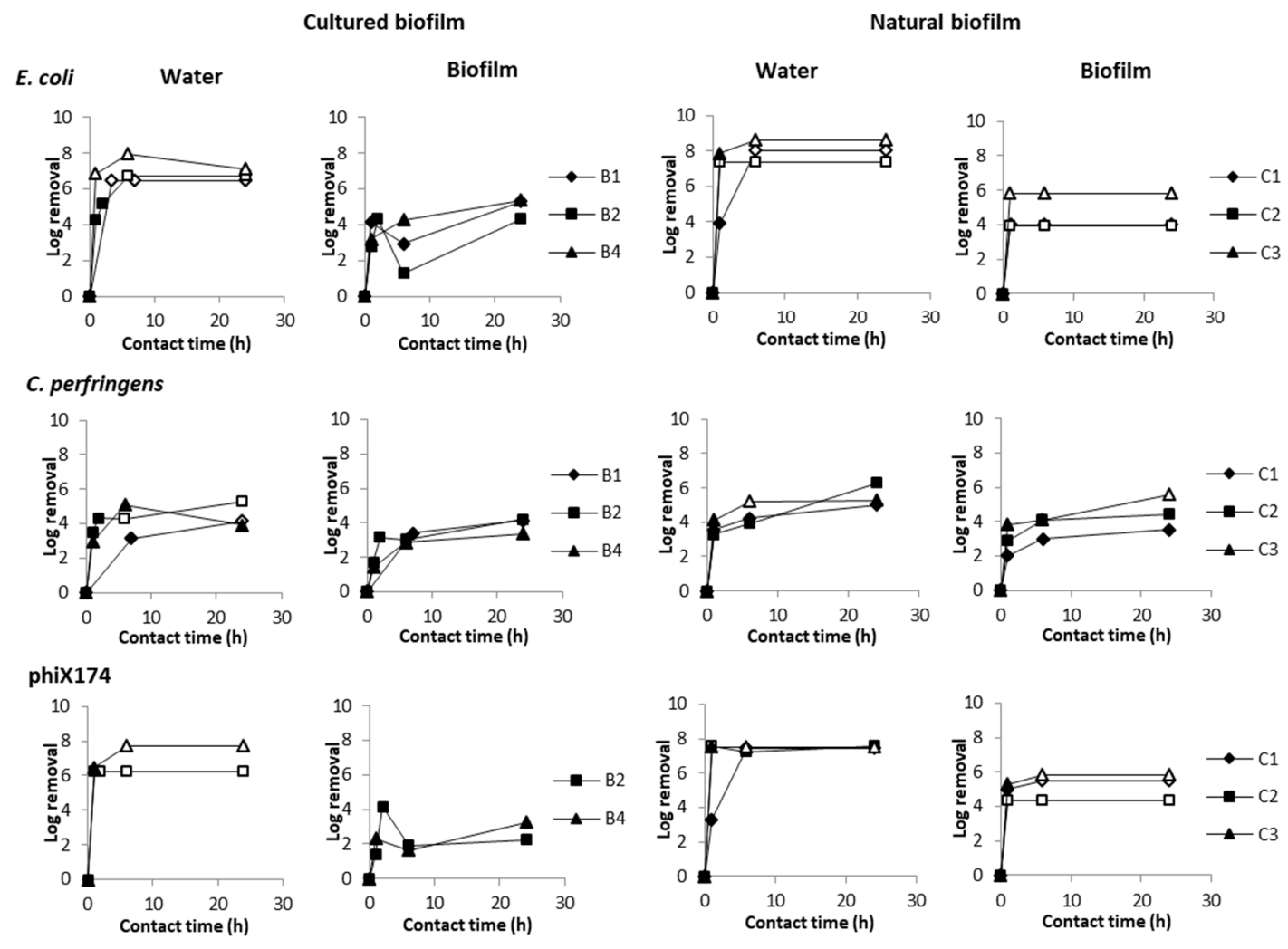

Figure 7. Log removal of microorganisms by chlorination $(10 \mathrm{mg} / \mathrm{L})$ from the water and biofilm of a cultured and natural biofilm in log removal. Markings in white indicate a result below the detection limit and is thus a '>value' in log removal.

It has long been known that chlorine disinfection is highly active against most bacteria $[31,32]$ and viruses [33,34]. A CT-value around $1 \mathrm{mg} \mathrm{min} / \mathrm{L}$ is often sufficient for 3-4 log reduction of 
these microorganisms. However, most protozoa and spores are highly resistant against chlorine and inactivation is limited [35,36]. In our experiments C. perfringens spores were most resistant to chlorine, but still 3-5 log was inactivated after $24 \mathrm{~h}$ incubation (CT: 14,400 $\mathrm{mg} \mathrm{min} / \mathrm{L}$ ). In another study inactivation was lower: $1.7 \log$ C. perfringens spores were inactivated upon incubation in a $5 \mathrm{mg} / \mathrm{L}$ chlorine solution for $24 \mathrm{~h}$ (CT: $7200 \mathrm{mg} \mathrm{min/L)} \mathrm{[37].} \mathrm{In} \mathrm{the} \mathrm{same} \mathrm{study,} \mathrm{Cryptosporidium} \mathrm{paroum} \mathrm{spores}$ were completely resistant to the chlorine treatment. Bacillus subtilis spores were not inactivated during 180-min incubation in a 1-10 mg/L chlorine solution (CT: 180-1800 mg min/L) [22]. One of the reasons that cause the differences in inactivation kinetics may be the age of the spores. From UV-disinfection studies it is known that young spores are more vulnerable to UV disinfection then older spores [38]. It is possible that the same principle holds for chlorine disinfection, in that older spores are more resistant to chlorine than young spores. Disinfection studies in which the indicator viruses MS2 and phiX174 were incubated with $0.5 \mathrm{mg} / \mathrm{L}$ chlorine a $>3.5 \mathrm{log}$ reduction within $30 \mathrm{~min}$ for MS2 and 1 min for phiX174 was observed (CT: 15 and $0.5 \mathrm{mg} \mathrm{min} / \mathrm{L}$ ) [39]. In another study, applying 1-10 mg/L chlorine, a >5 log inactivation of free-suspended MS2 bacteriophage was achieved (CT: 15-20 mg $\mathrm{min} / \mathrm{L}$ ) [22]. PhiX174 was also quickly inactivated in our study (6 log inactivation, CT: $600 \mathrm{mg} \mathrm{min} / \mathrm{L}$ ). However, as inactivation was not measured in the first hour the results cannot be directly compared to literature.

For the same reason the inactivation kinetics of E. coli in our study (4-7 log, CT: $600 \mathrm{mg} \mathrm{min} / \mathrm{L}$ ) cannot be compared directly to literature in which $E$. coli seems apparently more vulnerable to chlorine (5-6 log inactivation within $5 \mathrm{~min}$ at $1 \mathrm{mg} / \mathrm{L} \mathrm{[22]} \mathrm{or} 4 \log$ at $0.5 \mathrm{mg} / \mathrm{L}$ within $30 \mathrm{~s}$ ) [32].

\subsection{Application to Real-Life Situation}

The flushing and disinfection experiments show that microorganisms in the water phase of a distribution system are readily removed by flushing. Although removal by flushing is not complete, in a real-life situation flushing is often probably sufficient as a contamination is likely to harbor less microorganisms than that were dosed in these experiments. A 2-3 log removal efficacy is sufficient in these cases. The tested flushing velocities $(0.3 \mathrm{~m} / \mathrm{s}$ or $1.5 \mathrm{~m} / \mathrm{s})$ yielded similar removal efficiencies. However, the microbial contamination was suspended in water and not bound to sediment particles which may make removal more difficult as a sufficient flow velocity is required to resuspend the particles in to the water phase. A previous study showed that lower flushing velocities $(0.25-0.4 \mathrm{~m} / \mathrm{s})$ are sufficient for removal of sediment particles from a $100 \mathrm{~mm}$ pipe, however resuspension is likely to be more effective at $1.5 \mathrm{~m} / \mathrm{s}$ compared to $0.3 \mathrm{~m} / \mathrm{s}$. Therefore, it remains recommendable to aim for a flushing velocity of $1.5 \mathrm{~m} / \mathrm{s}$. In situations in which $1.5 \mathrm{~m} / \mathrm{s}$ cannot be reached due to practical reasons, flushing with $0.3 \mathrm{~m} / \mathrm{s}$ can be used to remove the contamination from the water phase, but a less efficient removal of particles with attached microorganisms should be taken into account.

If a contamination enters the drinking water pipe and is not removed immediately, the microorganisms will have bound to the biofilm, and chlorine disinfection is required to inactivate these microorganisms. Chlorine disinfection should also be considered when the repair works have a high risk, for example when leaking sewage pipes are located close to or above the drinking water pipe line. The surrounding ground water or soil is likely to contain high numbers of microorganisms and even a contamination with a small amount of water or soil may introduce a large number of microorganisms. In these cases disinfection with a high chlorine concentration is required to inactivate the bound microorganisms and to ensure the microbiological safety of drinking water. Other options to remove, and thus clean the biofilm are available, for example, (ice) pigging during which an ice slurry is pushed through the pipe, removes the pipe wall biofilm and (nearly) all loose sediment particles. However, chlorination can be performed on a short notice, which is not possible for (ice) pigging.

Prevention of ingress of fecal contamination into the network remains pivotal in protecting the public health and requires strict adherence to hygienic working procedures. If the network becomes contaminated, protecting the public health remains the first priority. Therefore, not only flushing, and possibly chlorination, should be applied, but also a (preventive) boil water advice to the consumers. 
Once the distribution system is contaminated it remains important to first localize and isolate the contamination source before performing flushing and chlorination.

\section{Conclusions}

Flushing and chlorine disinfection experiments in a pipe-loop system show that (1) sampling of water from the distribution system for microbiological monitoring can be performed $1 \mathrm{~h}$ after flushing, (2) small microbial contaminations in the water phase can be effectively flushed out of the system, (3) a contamination with sand was not completely removed from the system and present in the first few meters, (4) flushing with more than the prescribed three volume replacements removes only a limited number of extra microorganisms, (5) after high risk repair works or incidents shock chlorination is advised to ensure the microbiological safety of the drinking water as flushing is not efficient enough, (6) experiments with pipes with a cultured biofilm yield comparable results to pipes with a natural biofilm. For future experiments pipes with a cultured biofilm can be used, instead of pipes with a natural biofilm which have to be extracted from a distribution system by a drinking water company.

Author Contributions: Conceptualization, N.v.B., L.M.H. and G.M.; Investigation, N.v.B. and A.v.d.V.; Methodology, N.v.B., L.M.H. and A.v.d.V.; Visualization, N.v.B.; Writing—original draft, N.v.B.; Writing一review \& editing, N.v.B. and G.M.

Funding: The research was funded by the Dutch drinking water companies through the Joint Research Program.

Acknowledgments: We would like to thank the Dutch drinking water companies, especially Jamal El Majjaoui (Dunea), Falco van Driel (Water Maatschappij Limburg) and Agata Donocik (Brabant Water), for arranging the excavation of the pipe segments from the real distribution network. The experiments would not have been possible without the technical assistance of the Laboratory of Microbiology of KWR.

Conflicts of Interest: The authors declare no conflict of interest.

\section{References}

1. Karim, M.R.; Abbaszadegan, M.; LeChevallier, M. Potential for pathogen intrusion during pressure transients. J. Am. Water Works Assoc. 2003, 95, 134-146. [CrossRef]

2. Besner, M.C.; Broseus, R.; Lavoie, J.; Giovanni, G.D.; Payment, P.; Prevost, M. Pressure monitoring and characterization of external sources of contamination at the site of the payment drinking water epidemiological studies. Environ. Sci. Technol. 2010, 44, 269-277. [CrossRef] [PubMed]

3. Teunis, P.F.; Moe, C.L.; Liu, P.; Miller, S.E.; Lindesmith, L.; Baric, R.S.; Le Pendu, J.; Calderon, R.L. Norwalk virus: How infectious is it? J. Med. Virol. 2008, 80, 1468-1476. [CrossRef] [PubMed]

4. Messner, M.J.; Berger, P.; Nappier, S.P. Fractional poisson-A simple dose-response model for human norovirus. Risk Anal. 2014, 34, 1820-1829. [CrossRef] [PubMed]

5. Nygard, K.; Wahl, E.; Krogh, T.; Tveit, O.A.; Bohleng, E.; Tverdal, A.; Aavitsland, P. Breaks and maintenance work in the water distribution systems and gastrointestinal illness: A cohort study. Int. J. Epidemiol. 2007, 36, 873-880. [CrossRef] [PubMed]

6. Save-Soderbergh, M.; Bylund, J.; Malm, A.; Simonsson, M.; Toljander, J. Gastrointestinal illness linked to incidents in drinking water distribution networks in Sweden. Water Res. 2017, 122, 503-511. [CrossRef] [PubMed]

7. Payment, P.; Siemiatycki, J.; Richardson, L.; Renaud, G.; Franco, E.; Prevost, M. A prospective epidemiological study of gastrointestinal health effects due to the consumption of drinking water. Int. J. Environ. Health Res. 1997, 7, 5-31. [CrossRef]

8. Payment, P.; Richardson, L.; Siemiatycki, J.; Dewar, R.; Edwardes, M.; Franco, E. A randomized trial to evaluate the risk of gastrointestinal disease due to consumption of drinking water meeting current microbiological standards. Am. J. Public Health 1991, 81, 703-708. [CrossRef]

9. Nygard, K.; Andersson, Y.; Rottingen, J.A.; Svensson, A.; Lindback, J.; Kistemann, T.; Giesecke, J. Association between environmental risk factors and campylobacter infections in Sweden. Epidemiol. Infect. 2004, 132, 317-325. [CrossRef] 
10. Hellard, M.E.; Sinclair, M.I.; Forbes, A.B.; Fairley, C.K. A randomized, blinded, controlled trial investigating the gastrointestinal health effects of drinking water quality. Environ. Health Perspect. 2001, 109, 773-778. [CrossRef]

11. Colford, J.M., Jr.; Wade, T.J.; Sandhu, S.K.; Wright, C.C.; Lee, S.; Shaw, S.; Fox, K.; Burns, S.; Benker, A.; Brookhart, M.A.; et al. A randomized, controlled trial of in-home drinking water intervention to reduce gastrointestinal illness. Am. J. Epidemiol. 2005, 161, 472-482. [CrossRef]

12. Ercumen, A.; Gruber, J.S.; Colford, J.M., Jr. Water distribution system deficiencies and gastrointestinal illness: A systematic review and meta-analysis. Environ. Health Perspect. 2014, 122, 651-660. [CrossRef] [PubMed]

13. Besner, M.C.; Prevost, M.; Regli, S. Assessing the public health risk of microbial intrusion events in distribution systems: Conceptual model, available data, and challenges. Water Res. 2011, 45, 961-979. [CrossRef] [PubMed]

14. Teunis, P.F.; Xu, M.; Fleming, K.K.; Yang, J.; Moe, C.L.; Lechevallier, M.W. Enteric virus infection risk from intrusion of sewage into a drinking water distribution network. Environ. Sci. Technol. 2010, 44, 8561-8566. [CrossRef]

15. Yang, J.; LeChevallier, M.W.; Teunis, P.F.; Xu, M. Managing risks from virus intrusion into water distribution systems due to pressure transients. J. Water Health 2011, 9, 291-305. [CrossRef]

16. Davis, M.J.; Janke, R. Development of a Probabilistic Timing Model for the Ingestion of Tap Water. J. Water Resour. Plan. Manag. 2009, 135, 397-405. [CrossRef]

17. Blokker, E.; Smeets, P.; Medema, G. QMRA in the Drinking Water Distribution System. Procedia Eng. 2014, 89, 151-159. [CrossRef]

18. Blokker, M.; Smeets, P.; Medema, G. Quantitative microbial risk assessment of repairs of the drinking water distribution system. Microb. Risk Anal. 2017. [CrossRef]

19. Teunis, P.F.M.; Chappell, C.L.; Okhuysen, P.C. Cryptosporidium Dose-Response Studies: Variation Between Hosts. Risk Anal. 2002, 22, 475-485. [CrossRef]

20. Regli, S.; Rose, J.B.; Haas, C.N.; Gerba, C.P. Modeling the Risk From Giardia and Viruses in Drinking Water. J. Am. Water Works Assoc. 1991, 83, 76-84. [CrossRef]

21. Teunis, P.; van der Heijden, O.; van der Giessen, J.; Havelaar, A.H. THE DOSE-RESPONSE RELATION in Human Volunteers for Gastro-Intestinal Pathogens; Rijksinstituut Voor Volksgezondheid en Milieu RIVM: Bilthoven, The Netherlands, 1996.

22. Yang, J.; Schneider, O.D.; Jjemba, P.K.; Lechevallier, M.W. Microbial Risk Modeling for Main Breaks. J. Am. Water Works Assoc. 2015, 107, E97-E108. [CrossRef]

23. Krishnan, R.P.; Randall, P. Pilot-Scale Tests and Systems Evaluation for the Containment, Treatment, and Decontamination of Selected Materials from TEE Building Pipe Loop Equipment; U.S. Environmental Protection Agency: Washington, DC, USA, 2008.

24. McMinn, B.R.; Ashbolt, N.J.; Korajkic, A. Bacteriophages as indicators of faecal pollution and enteric virus removal. Lett. Appl. Microbiol. 2017, 65, 11-26. [CrossRef]

25. Wingender, J.; Flemming, H.C. Contamination potential of drinking water distribution network biofilms. Water Sci. Technol. 2004, 49, 277-286. [CrossRef]

26. Langmark, J.; Storey, M.V.; Ashbolt, N.J.; Stenstrom, T.A. Biofilms in an urban water distribution system: Measurement of biofilm biomass, pathogens and pathogen persistence within the Greater Stockholm Area, Sweden. Water Sci. Technol. 2005, 52, 181-189. [CrossRef]

27. Bauman, W.J.; Nocker, A.; Jones, W.L.; Camper, A.K. Retention of a model pathogen in a porous media biofilm. Biofouling 2009, 25, 229-240. [CrossRef]

28. Paris, T.; Skali-Lami, S.; Block, J.C. Probing young drinking water biofilms with hard and soft particles. Water Res. 2009, 43, 117-126. [CrossRef]

29. Helmi, K.; Skraber, S.; Gantzer, C.; Willame, R.; Hoffmann, L.; Cauchie, H.M. Interactions of Cryptosporidium parvum, Giardia lamblia, vaccinal poliovirus type 1, and bacteriophages phiX174 and MS2 with a drinking water biofilm and a wastewater biofilm. Appl. Environ. Microbiol. 2008, 74, 2079-2088. [CrossRef]

30. Mains, D.W. American Water Works Association. In ANSI/AWWA C651-14; American Water Works Association: New York, NY, USA, 2015. [CrossRef]

31. Blaser, M.J.; Smith, P.F.; Wang, W.L.; Hoff, J.C. Inactivation of Campylobacter jejuni by chlorine and monochloramine. Appl. Environ. Microbiol. 1986, 51, 307-311. 
32. Zhao, T.; Doyle, M.P.; Zhao, P.; Blake, P.; Wu, F.M. Chlorine inactivation of Escherichia coli O157:H7 in water. J. Food Prot. 2001, 64, 1607-1609. [CrossRef]

33. Engelbrecht, R.S.; Weber, M.J.; Salter, B.L.; Schmidt, C.A. Comparative inactivation of viruses by chlorine. Appl. Environ. Microbiol. 1980, 40, 249-256.

34. Thurston-Enriquez, J.A.; Haas, C.N.; Jacangelo, J.; Gerba, C.P. Chlorine inactivation of adenovirus type 40 and feline calicivirus. Appl. Environ. Microbiol. 2003, 69, 3979-3985. [CrossRef] [PubMed]

35. Jarroll, E.L.; Bingham, A.K.; Meyer, E.A. Effect of chlorine on Giardia lamblia cyst viability. Appl. Environ. Microbiol. 1981, 41, 483-487.

36. Shields, J.M.; Hill, V.R.; Arrowood, M.J.; Beach, M.J. Inactivation of Cryptosporidium parvum under chlorinated recreational water conditions. J. Water Health 2008, 6, 513-520. [CrossRef] [PubMed]

37. Venczel, L.V.; Arrowood, M.; Hurd, M.; Sobsey, M.D. Inactivation of Cryptosporidium parvum Oocysts and Clostridium perfringens Spores by a Mixed-Oxidant Disinfectant and by Free Chlorine. Appl. Environ. Microbiol. 1997, 63, 4625. [PubMed]

38. Hijnen, W.A.; Beerendonk, E.F.; Medema, G.J. Inactivation credit of UV radiation for viruses, bacteria and protozoan (oo)cysts in water: A review. Water Res. 2006, 40, 3-22. [CrossRef]

39. Sobsey, M.D.; Fuji, T.; Shields, P.A. Inactivation of Hepatitis a Virus and Model Viruses in Water by Free Chlorine and Monochloramine. Water Sci. Technol. 1988, 20, 385-391. [CrossRef]

(C) 2019 by the authors. Licensee MDPI, Basel, Switzerland. This article is an open access article distributed under the terms and conditions of the Creative Commons Attribution (CC BY) license (http://creativecommons.org/licenses/by/4.0/). 